\title{
Proportionate probability sampling
}

By Margaret Hawthorn and Elaine Goettler

\section{A technique to find out the needs of library users and nonusers}

$\mathbf{T}$ oday's financial stringencies as well as good management practice have forced academic libraries constantly to review services and make decisions as to where retrenchment or, optimistically, expansion will take place. A sophisticated and comprehensive user survey or needs assessment provides a solid starting point for the decision process. ${ }^{1}$ But when the question of updating user information arose at Erindale College, a satellite campus of the University of Toronto, we very much wanted to improve on previous survey efforts.

\section{Survey needs}

As in many other libraries, questionnaires had been handed out at the library door during sample time periods, surveying some of those students who entered the library but obtaining no information on students who were not library users. This time we wanted:

- To differentiate between nonusers who judged that they did not need the library and students who had found it unsatisfactory at some point and no longer used it for their library needs

- To obtain a statistically valid survey of student library needs by major area of study to make sure we were providing essential library resources in every case.

- To gather an accurate student "vote" on possible library improvements, information needed by a recently constituted Student Library Enhancement Fund committee.

- To meet our requirements, we decided to try a statistical approach borrowed from so- ciological survey research: the proportionate probability sample.

\section{Proportionate probability sampling}

Proportionate probability sampling or proportional allocation is a statistical approach which proves particularly useful for a survey of student library use. Using this sampling technique involves obtaining student enrollment figures by subject area and by year from a registrar's office and then apportioning a sample to match the distribution outlined. In our case, first a sample size of 550 representing $10 \%$ of college enrollment was selected. We then divided the sample into a group representing first-year students $(10 \%$ of 1,200$)$ and a group representing upper-year students $(10 \%$ of 4,300$)$. (Upperyear students have a greater range of courses available which may be taken in various sequences not necessarily restricted by year of study.)

Next, individual classes in different subject areas were chosen to represent the proportion of subject enrollment within the two major groups representing year of study. For instance, if first-year English represented $25 \%$ of the firstyear enrollment $(1,200)$, then an English 101 class (or classes) totalling 30 students, or $25 \%$ of the first-year sample (120), would be selected to receive questionnaires. In this way, each surveyed class was a sample of similar students throughout the college population.

\section{Questionnaire distribution}

A two-sided questionnaire sheet on library services was designed, timed to take no more than five minutes to complete. The time frame and the comprehensibility of the questions were pretested using library student assistants.

Then faculty teaching the "sample" classes were contacted and the project explained. In 


\section{Receive first class treatment at Ballen...}


\section{no matter what your size.}

Whether your order is for a thousand books or just one, whether you are a prestigious university, medical school, or a little-known junior college, every Ballen customer receives our legendary one-to-one customized service.

That means you'll have a personal Ballen customer service representative to answer questions, report status and solve problems. You'll have a specific location in our staging area for maximum quality control. You'll have instant access to important information through BallenNet ${ }^{\mathrm{TM}}$, our interactive on-line service for order entry data and current order status. Even direct telephone access to a Ballen corporate officer, if necessary.

And despite our elephantine inventory of over 100,000 titles, with thousands of books shipped every week, our return rate squeaks in at less than $1 \%$ - the industry's lowest.

Find out how you can reap the big benefits of Ballen's personal service. Call Toll-Free (800) 645-5237 or $\operatorname{Fax}(516) 864-5850$.

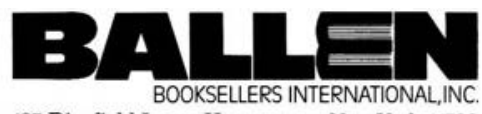


most cases, permission was given for use of the first five minutes of class time to distribute and collect questionnaires. If not, another class was selected that fit the enrollment profile.

Instructors were present and the response rate was close to $100 \%$.

\section{Analysis and results}

The answers were coded on the questionnaire itself and analyzed using the Statistical Analysis System program. Counting our respondents by year and major validated our use of proportionate probability sampling. Our sample corresponded very closely to the actual distribution of the student population, although part-time students were underrepresented, as they tend to cluster in certain classes rather than be randomly distributed across subject areas.

Why were some students not using the library? Collection inadequacies, too-short hours, and overcrowded study space emerged as major reasons. Some subjects, of course, did not require library use. Even among those who did use the library frequently, over half replied that it did not fill all their library needs and a large percentage used other university and public libraries as well.

It was then open to us to make the assumption that if the suggested improvements were made, if longer hours and more study space were provided and more books and journals purchased, more of our students would use the library and use it more often.

Were there differences in library needs among the subject areas? Using a chi-square analysis, we found that reported use of and need for journals differed significantly, with almost $100 \%$ of science students answering that journals were "very important" in a number of categories. Specialized reference handbooks and reports were rated as "important" by students in social sciences and humanities. Differences emerged in the use of document delivery services and, most interestingly, in reported use of the library with science students using it significantly more often than those in the humanities.

We felt that we had gained a clearer picture of the student body as library users or nonusers within subject areas.

What library improvements would be most popular with students? More study space $(87 \%)$, more reserve material $(85 \%)$, more staff help (76\%), more new books (78\%), more journals (51\%), and longer hours (61\%) were among the most frequently checked. Students on the Library Enhancement Fund Committee have been working on funding these improvements with some success since the survey was done.

\section{Conclusions}

Once the sample classes had been selected, the work involved in carrying out a proportionate probability survey was no greater than in previous, more conventional surveys that had been done. With these results, however, we were able to press for budget improvements and to recommend expenditures to the student committee based on graphs incorporating collegewide information.

Now that a number of the improvements so clearly requested have been implemented (journal subscriptions have increased as has our monograph budget, more study space is on the way, and hours have been lengthened) we anticipate redoing the survey to ensure that the library is meeting the needs of our current student body.

By using the proportionate probability sampling technique outlined here, we gathered accurate and powerful data from our library survey. The staff time and effort expended were more than justified by the range and the success of subsequent applications.

\section{Notes}

${ }^{1}$ Robert C. Newhouse, "A library essential: Needs assessment," Library Review (Glasgow, Scotland) 39 (February 1990): 33-36.

\section{Share your opinion with C\&RL News readers}

Do you feel strongly about a particular issue and want to share your thoughts with a wider audience than just your colleagues down the hall? Now you have the opportunity to share your thoughts with a national audience. CERL News is looking for well-reasoned commentaries on issues of interest to academic and research librarians for its column, "The Way I See It." Essays should be 750 to 1,000 words and should be sent to "The Way I See It," CERL News, ACRL, 50 E. Huron St., Chicago, IL 60611-2795; fax: (312) 280-7663; e-mail: U38398@UICVM. 